\title{
Nano SiC Reinforced Copper Nanocomposite by a Simple Electrodeposition Method
}

\author{
S. Ramalingam
}

\begin{abstract}
The $\mathrm{Cu}$ and $\mathrm{Cu}$-SiCnanocomposite coatings were prepared by a simple electrodeposition technique from acidic copper sulphate electrolyte using SiC nanoparticles with an average particles size of $50 \mathrm{~nm}$ under optimized bath composition and preparation conditions for possible electrical contact material applications such as electrical switch and wiring boards where higher electrical conductivity and thermal conductivity is required. The scope of the present study is to enhance the strength, mechanical, corrosion and wear resistance properties of $\mathrm{Cu}$-SiCnanocomposite compared to pure $\mathrm{Cu}$ coatings. The as prepared $\mathrm{Cu}$ and $\mathrm{Cu}$-SiCnanocomposites were characterized for structural, mechanical and corrosion resistance properties by EDX, XRD, FESEM, Vickers microhardness tester and AC-impedance and Tafel polarization techniques. The elemental composition (wt\% of $\mathrm{Cu}$ and $\mathrm{SiC}$ nanoparticles) of $\mathrm{Cu}$-SiCnanocomposites was analyzed by $\mathrm{EDX}$ coupled with FESEM analysis confirms the presence of nanoSiC in the copper matrix and they were $89 \mathrm{wt} \%$ of $\mathrm{Cu}$ and 11 wt\% of SiC nanoparticles respectively. The surface morphology of $\mathrm{Cu}$ and $\mathrm{Cu}$-SiCnanocomposites was studied by FESEM analysis shows that SiC nanoparticles were uniformly dispersed in the surface of the copper matrix compared to pure copper. The crystallite structure and grain size of the $\mathrm{Cu}$ and Cu-SiCnanocomposite electrodeposits was measured by XRD analysis. From the XRD results, the grain size calculated using Debye-Scherrer's formula was $\sim 35 \mathrm{~nm}$ for pure Cu and $\sim 33 \mathrm{~nm}$ $\mathrm{Cu}$-SiCnanocomposite. The crystallite structure of $\mathrm{Cu}$ and Cu-SiCnanocomposites was fcc (face centered cubic) and the preferred orientation of the plane was (220). The microhardness of Cu-SiCnanocomposite coating increased with increasing SiC nanoparticles concentration in the bath compared to pure $\mathrm{Cu}$ coating. The corrosion resistance measurements were performed for the pure $\mathrm{Cu}$ and $\mathrm{Cu}$-SiCnanocomposite coatings by electrochemical impedance spectroscopy (EIS) and Tafel polarization techniques. It shows that, $\mathrm{Cu}$-SiCnanocomposites has high corrosion resistance than pure $\mathrm{Cu}$ in $3.5 \mathrm{wt} \% \mathrm{NaCl}$ solution.
\end{abstract}

Keywords: Electrodeposition, Cu-SiCnanocomposite, SiC nanoparticles, Corrosion resistance, Microhardness.

\section{INTRODUCTION}

In the recent years, on the basis of production and utilization, the copper and copper based alloys possess third position after iron \& steel and aluminum, due to its exceptional electrical conductivity, thermal conductivity and good corrosion resistance [1-2].Though copper is an excellent electrical and thermal conductor material, it possesses low wear resistance and mechanical strength. In

Revised Manuscript Received on December 18, 2019

* Correspondence Author

S. Ramalingam*, Department of Chemistry, School of Advanced Sciences, Kalasalingam Academy of Research and Education(Deemed to be University), Krishnankoil-626126. Tamil Nadu, India.

Email: rama.s.lingam@gmail.com. order to increase the mechanical strength, corrosion and wear resistance, the second phase nanoparticles reinforced metal matrix nanocomposites has been prepared and reported in the earlier are $\mathrm{Cu}-\mathrm{TiO}_{2}, \mathrm{Cu}-\mathrm{CeO}_{2}, \mathrm{Cu}-\mathrm{SiO}_{2}$, $\mathrm{Cu}-\mathrm{ZrO}_{2}, \mathrm{Cu}-\mathrm{Al}_{2} \mathrm{O}_{3}, \mathrm{Cu}-\mathrm{Si}_{3} \mathrm{~N}_{4}, \mathrm{Cu}-\mathrm{CNTs}$ etc. [3-12].These second phase nanoparticles reinforced metal matrix nanocomposites showed increased hardness and better corrosion and wear resistance compared to particle free metal electrodeposits [13-22]. The advantages of electrodeposition is an excellent low cost and low temperature technique compared to the conventional methods such as powder metallurgy, sputtering, spin coating, thermal spraying, centrifugal casting etc., which is used to coat over the complicated conductive surfaces. Electrodeposition is an industrially viable and economically preferable technique for the deposition of metals and alloys and metal matrix nanocomposites (MMNCs) [23-32].

The SiCnanoparticlesare very hard materials and possess high strength and high thermal conductivity, good corrosion and wear resistance and low cost material. This property of $\mathrm{SiC}$ nanoparticles makes them useful in ceramic applications such as ceramic bearing, textile ceramics, high frequency ceramics and ceramic engine parts. Also, SiC nanoparticles are resistant to oxidation at high temperatures and has very high melting point of $2730^{\circ} \mathrm{C}$. In order to increase the strength, corrosion resistance, wear resistance and heat resistance of composite materials, currently the $\mathrm{SiC}$ nanoparticles can be used.

Presently, the production of copper matrix nanocomposites by various methods has increased due to their potential industrial applications such as electrical contacts and connector materials in electrical devices [1-2][33-38]. The aim and scope of the present work is to synthesize nanoSiC reinforced $\mathrm{Cu}$ matrix nanocomposites by simple electrodeposition method using acid copper sulphate electrolytes with optimized bath composition and process conditions. The synthesized $\mathrm{Cu}$-nanoSiC composites were characterized for structural, mechanical and corrosion resistance properties by EDX, FESEM, XRD, Vickers hardness tester and Electrochemical AC impedance and Tafel polarization techniques and the results were compared with the pure copper electrodeposit. 


\section{II.EXPERIMENTAL METHODS}

\section{A. Electrodeposition of Copper and Cu-SiCNanocomposites}

The chemicals, copper sulphatepentahydrate $\left(\mathrm{CuSO}_{4}\right.$. $\left.5 \mathrm{H}_{2} \mathrm{O}\right)$, sulphuric acid $\left(\mathrm{H}_{2} \mathrm{SO}_{4}\right)$, gelatin and $\mathrm{SiC}$ nanoparticles (size $50 \mathrm{~nm}$ ) used for the electrodeposition of copper and $\mathrm{Cu}$-SiCnanocomposites are pure analytical grade and purchased from Merck and Sisco research laboratories (SRL).

The electroplating bath was prepared by weighing the chemicals as per the bath composition and dissolved in deionized water and kept in magnetic stirrer for 10 minutes to ensure the complete dissolution of all the chemicals. The electrolytic grade pure copper anode and mechanically polished copper cathodes are used in the deposition process. First, the copper cathodes are cut in the machine to the required size $\left(4 \mathrm{~cm}^{2}\right.$ areas) and then polished with course and fine emery sheets and degreased in acetone to remove oil and grease from the surface of the cathodes. Then it is dipped in dilute $\mathrm{HCl}$ solution and then washed with distilled water and air dried to use in the deposition bath for the preparation of the composite coatings.

The copper sulphatepentahydrate $\left(\mathrm{CuSO}_{4} \cdot \mathrm{H}_{2} \mathrm{O}\right)(0.3 \mathrm{M})$ and sulphuric acid $\left(\mathrm{H}_{2} \mathrm{SO}_{4}\right)(1.3 \mathrm{M})$ solution is prepared with de-ionized water in $500 \mathrm{ml}$ beaker. To this $10 \mathrm{~g} / \mathrm{l}, 20 \mathrm{~g} / \mathrm{l}, 30$ $\mathrm{g} / \mathrm{l}$ and $40 \mathrm{~g} / \mathrm{l}$ of nanoSiC particles (size $50 \mathrm{~nm}$ ) are dispersed with gelatin additive $(1 \mathrm{~g} / \mathrm{l})$ separately and this solution is kept agitated for 6 to $8 \mathrm{hr}$ to ensure complete and uniform dispersion of nanoSiC in the electrolytic copper sulphate bath. Then, the pure copper anode and polished copper cathodes are immersed in the electrolytic bath and connected to the DC regulated power supply. The electrodeposition was carried out with the current density of $5 \mathrm{~A} / \mathrm{dm}^{2}$ for the duration of 60 minutes at $30^{\circ} \mathrm{C}$ [3][5][8][11]. The $\mathrm{pH}$ of the bath was maintained at $\sim 1$ throughout the process. The electroplating bath composition and preparation conditions are given in the Table1. After the completion of the deposition process, the samples were taken out from the bath, washed with distilled water and air dried. The particle free pure copper is also electroplated using the same bath composition without the addition of nanoSiC particles. The pore free, uniform and smooth surface samples were obtained with the thickness of $\sim 65 \mu \mathrm{m}$ by electrodeposition technique [3][5][8][11].

Table1: Bath composition and conditionsfor the electrodeposition of copper and $\mathrm{Cu}$-SiCnanocomposites

\begin{tabular}{|l|l|}
\hline \multicolumn{2}{|c|}{ Bath composition and operating parameters } \\
\hline $\mathrm{CuSO}_{4} .5 \mathrm{H}_{2} \mathrm{O}$ & $0.3 \mathrm{M}$ \\
\hline $\mathrm{H}_{2} \mathrm{SO}_{4}$ & $1.3 \mathrm{M}$ \\
\hline $\begin{array}{l}\mathrm{SiC} \text { nanoparticles } \\
(50 \mathrm{~nm})\end{array}$ & $0,10 \mathrm{~g} / \mathrm{l}, 20 \mathrm{~g} / \mathrm{l}, 30 \mathrm{~g} / \mathrm{l}, \& 40 \mathrm{~g} / \mathrm{l}$ \\
\hline Gelatin additive & $1 \mathrm{~g} / \mathrm{l}$ \\
\hline Current Density & $5 \mathrm{~A} / \mathrm{dm}^{2}$ \\
\hline $\mathrm{pH}$ & $\sim 1$ \\
\hline Temperature & $30^{\circ} \mathrm{C}$ \\
\hline Deposition Time & 60 minutes \\
\hline
\end{tabular}

Where $\mathrm{D}$ is the crystallite size and $\lambda$-is the wavelength of the radiation, $\beta$-is the full width at half maximum height (FWHM) of the peak. The microstructure and elemental composition of the $\mathrm{Cu}$-SiCnanocomposites was examined by FESEM coupled with EDX (Quanta FEG 250) analysis. The microhardness of the electrodeposited pure $\mathrm{Cu}$ and $\mathrm{Cu}$-SiCnanocomposites was measured by Vickers microhardness tester.

The corrosion resistance of the electrodeposits of pure $\mathrm{Cu}$ and $\mathrm{Cu}$-SiCnanocomposites was measured by electrochemical impedance spectroscopy (EIS) and Potentiodynamic polarization techniques. The corrosion rate (CR) was calculated using $\mathrm{i}_{\text {corr }}$ (corrosion current) values by the formula [3][5][8][11];

$$
\text { Corrosion rate }(\mathrm{CR})=\mathrm{k}\left(\frac{\mathrm{i}_{\text {corr }}}{\rho}\right) \mathrm{EW}
$$

Where, Corrosion rate $(\mathrm{CR})$ is given in $\mathrm{mm} / \mathrm{yr}, k=3.27 \times 10^{-3}$ $\mathrm{mm} \mathrm{g} / \mu \mathrm{A} \mathrm{cm} \mathrm{yr,} \rho=$ Density of $\mathrm{Cu}\left(8.96 \mathrm{~g} / \mathrm{cm}^{3}\right), \mathrm{EW}=$ Equivalent weight of $\mathrm{Cu}$ (31.77).

\section{RESULTS AND DISCUSSIONS}

\section{A. EDX Analysis of Cu-SiCNanocomposites}

The weight $\%$ of elements present in the $\mathrm{Cu}$-SiCnanocomposites were analyzed by Energy dispersive $\mathrm{X}$-ray spectroscopy (EDX) analysis. The representative EDX spectrum for the electrodeposited $\mathrm{Cu}-\mathrm{SiC} \quad(30 \mathrm{~g} / \mathrm{l})$ nanocomposites is shown in Fig. 1.

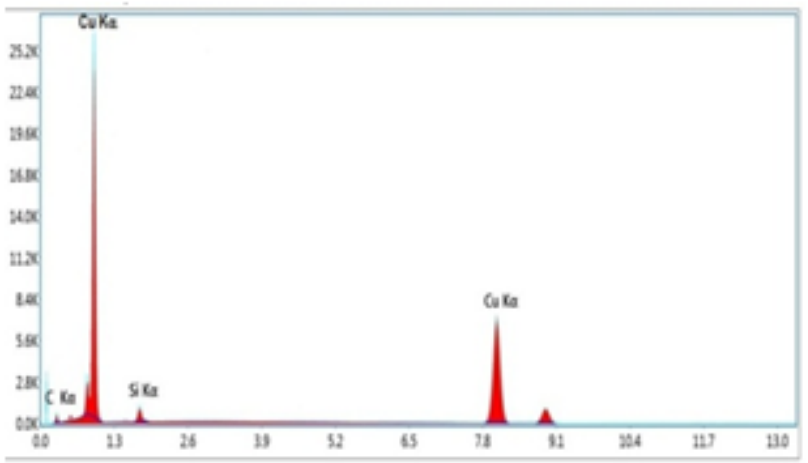

Fig. 1 EDX Spectrum of $\mathrm{Cu}-\mathrm{SiC}$ (30 g/l) nanocomposite coating.

The weight $\%$ of $\mathrm{Cu}$ and $\mathrm{SiC}$ nanoparticles present in the $\mathrm{Cu}-\mathrm{SiC}(30 \mathrm{~g} / \mathrm{l})$ nanocomposite coatings are $89 \%$ and $11 \%$ respectively, and the corresponding EDX mapping analysis pictures are shown in Fig.2(a-e). 
The EDX spectrum (Fig.1) and its mapping analysis pictures (Fig.2) confirm the presence of SiC nanoparticles on the copper matrix by electrodepositiontechnique. The presence of $11 \mathrm{wt} \%$ of $\mathrm{SiC}$ nanoparticles on the copper matrix enhances the mechanical and anti-corrosion properties of the $\mathrm{Cu}$-SiCnanocomposite coatings.
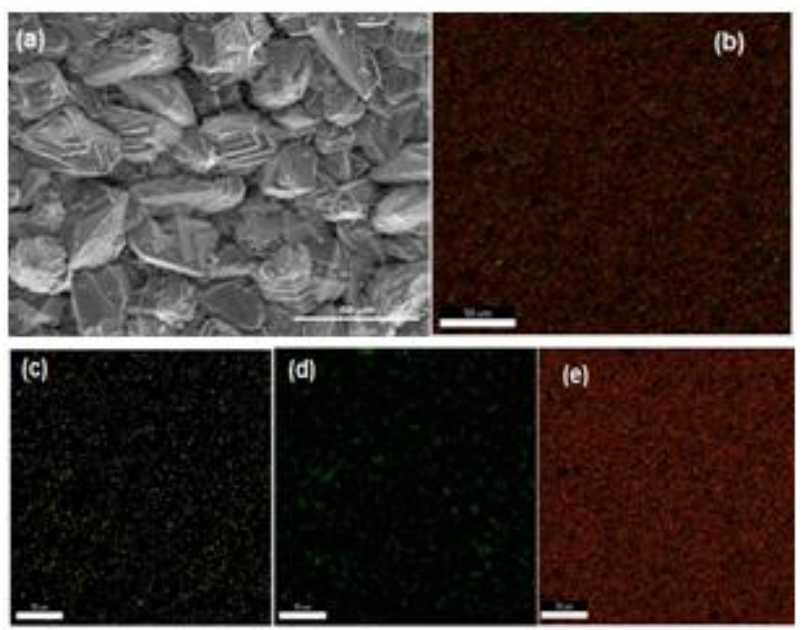

Fig.2(a-e) FESEM image and its EDX mapping pictures. (a) FESEM image of $\mathrm{Cu}-\mathrm{SiC}$ ( $30 \mathrm{~g} / \mathrm{l})$ nanocomposite, (b) EDX mapping picture of $\mathrm{Cu}-\mathrm{SiC}$

$(30 \mathrm{~g} / \mathrm{l})$ nanocomposite, (c) presence of $\mathrm{C}$, (d) presence of Si

(e) presence of $\mathrm{Cu}$.

\section{B. FESEM Analysis}

FESEM (Field Emission Scanning Electron Microscopy) (Quanta FE-SEM 250) was used to examine the Surface morphology of electrodeposited $\mathrm{Cu}$ and $\mathrm{Cu}-\mathrm{SiCnanocomposites}$ are shown in Fig.3(a\&b). The electrodeposited pure copper shows (Fig.3(a)) uniform cauliflower like crystallites with outward growth and the $\mathrm{Cu}-\mathrm{SiC}$ (30 g/l) nanocomposite shows (Fig.3(b)) uniformly distributed SiC nanoparticles on the surface of copper matrix. FESEM image (Fig.3(b)) confirm the presence of $\mathrm{SiC}$ nanoparticles on the surface of copper and these uniformly distributed $\mathrm{SiC}$ nanoparticles enhance the mechanical, corrosion and wear resistance properties of the $\mathrm{Cu}-\mathrm{SiCnanocomposite} \mathrm{coatings.}$

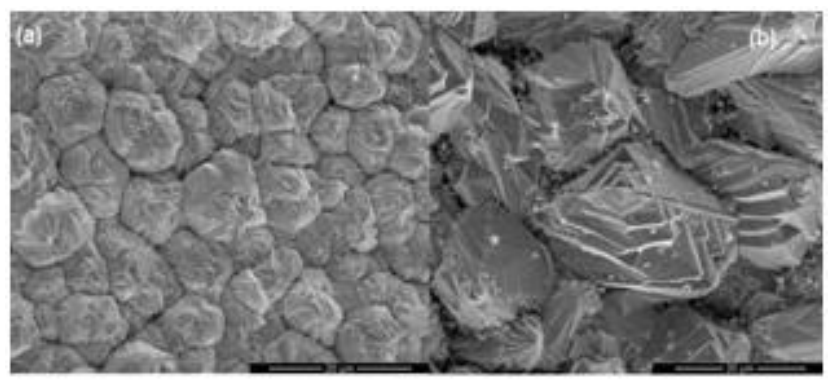

Fig. 3(a\&b). FESEM images of (a) Electrodeposited $\mathrm{Cu}$ and (b) $\mathrm{Cu}-\mathrm{SiC}$ (30 g/l) nanocomposite coating.

\section{XRD Analysis of $\mathrm{Cu}$ and $\mathrm{Cu}$-SiCNanocomposites}

The structural analysis was performed for the electrodeposited pure $\mathrm{Cu}$ and $\mathrm{Cu}-\mathrm{SiCnanocomposites} \mathrm{by}$ X-ray diffractometer (Bruker D8 Advance Eco) and their XRD pattern is shown in Fig.4. The grain size was calculated using Debye-Sherrer formula for the XRD patterns of $\mathrm{Cu}$ and $\mathrm{Cu}-\mathrm{SiCnanocomposites} \mathrm{were} \sim 35 \mathrm{~nm}$ for pure $\mathrm{Cu}$ and $\sim 33 \mathrm{~nm}$ for $\mathrm{Cu}-\mathrm{SiCnanocomposites}$. The crystallite structure of electrodeposited $\mathrm{Cu}$ and $\mathrm{Cu}-\mathrm{SiCnanocomposites} \mathrm{were} \mathrm{crystalline} \mathrm{fcc} \mathrm{(face} \mathrm{centered}$ cubic). It is observed that from the XRD studies, the electrodeposits of pure $\mathrm{Cu}$ and $\mathrm{Cu}-\mathrm{SiCnanocomposites}$ exhibit the preferred orientation along the plane (220) (Fig.4).The XRD patterns of pure $\mathrm{Cu}$ and $\mathrm{Cu}-\mathrm{SiCnanocomposites} \mathrm{are} \mathrm{matched} \mathrm{and} \mathrm{confirmed} \mathrm{with}$ the standard JCPDS copper reference (JCPDS Card No.040836) [3] [5][ 8][11].

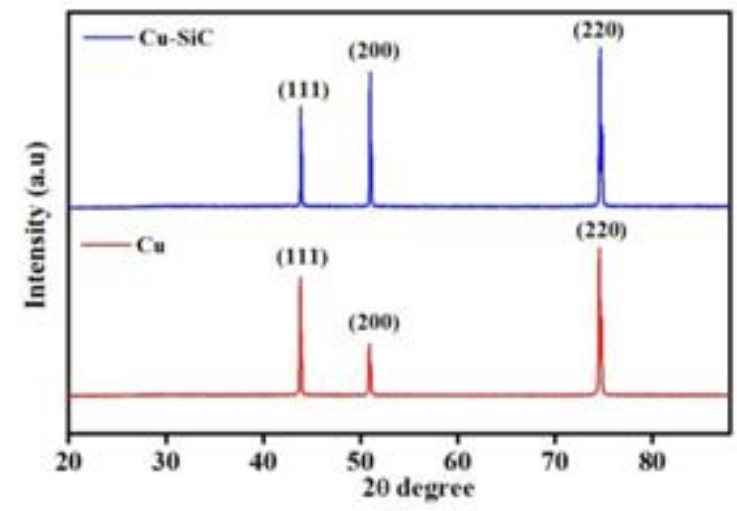

Fig.4. XRD Patterns of electrodeposited pure $\mathrm{Cu}$ and $\mathrm{Cu}-\mathrm{SiC}$ (30 g/l) nanocomposite coatings

\section{Effect of SiCNanoparticles Concentration}

Fig.5 shows the relationship between the SiC nanoparticles concentrations in the bath and the weight $\%$ of codepositedSiC in the electrodeposits. The weight $\%$ of codepositedSiC increases with increasing $\mathrm{SiC}$ nanoparticles concentrations in the bath from $10 \mathrm{~g} / \mathrm{l}$ to $30 \mathrm{~g} / \mathrm{l}$. Further increasing the $\mathrm{SiC}$ nanoparticles concentrations above 30 $\mathrm{g} / \mathrm{l}$, the weight $\%$ of codepositedSiC decreases for the $40 \mathrm{~g} / \mathrm{l}$ particles loading; this was confirmed by EDX analysis (Fig.5).

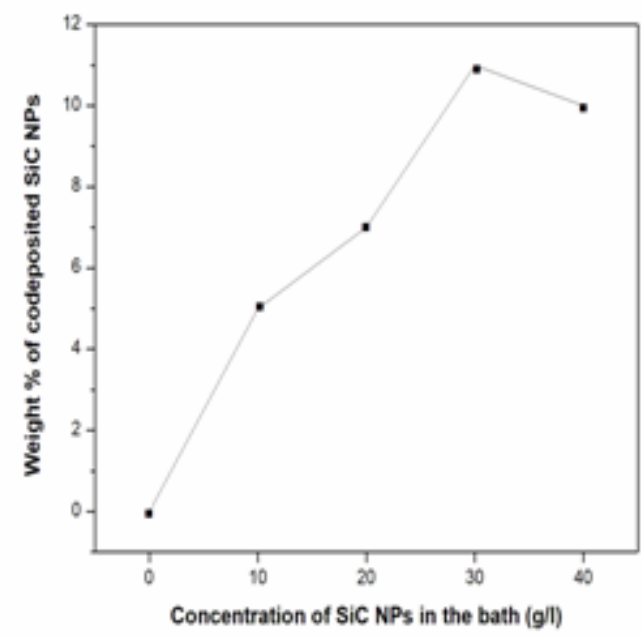

Fig. 5.Effect of concentration SiC NPs in the bath $(\mathrm{g} / \mathrm{l})$ andthe weight $\%$ of codepositedSiC NPs.

The mechanism of codeposition of $\mathrm{SiC}$ nanoparticles on the cathode surface follows the Guglielmi's two step adsorption model [39]. 
As per the Guglielmi's two step adsorption model, in the first step the $\mathrm{SiC}$ nanoparticles are loosely adsorbed and they are in equilibrium with the particles in the suspension. In the second step the SiC nanoparticles are irreversibly adsorbed on the cathode surface to form the $\mathrm{Cu}-\mathrm{SiCnanocomposite} \mathrm{thin} \mathrm{films} \mathrm{[39].}$

\section{E. Mechanical Properties}

\section{Vickers Microhardness}

Vickers microhardness was measured for electrodeposits of pure $\mathrm{Cu}$ and $\mathrm{Cu}-\mathrm{SiCnanocomposites}$ are shown in Fig.6. The microhardness of the $\mathrm{Cu}-\mathrm{SiCnanocomposites} \mathrm{increased}$ with increased content of $\mathrm{SiC}$ nanoparticles in the composite electrodeposits. The higher microhardness of the $\mathrm{Cu}-\mathrm{SiCnanocomposite}$ is due to the dispersion strengthening effect caused by the added $\mathrm{SiC}$ nanoparticles and the nucleation and grain refinement of $\mathrm{SiC}$ nanoparticles during the electrodeposition process [3][5][8]. This enhanced microhardness of the $\mathrm{Cu}-\mathrm{SiCnanocomposite} \mathrm{coatings} \mathrm{is} \mathrm{also} \mathrm{due} \mathrm{to} \mathrm{the} \mathrm{reduction}$ in grain size of $\mathrm{Cu}-\mathrm{SiCnanocomposite} \mathrm{coatings} \mathrm{(grain} \mathrm{size}$ of $\mathrm{Cu}-\mathrm{SiCnanocomposite}$ is $\sim 33 \mathrm{~nm}$ ) obtained by electrodeposition method and confirmed by XRD analysis.

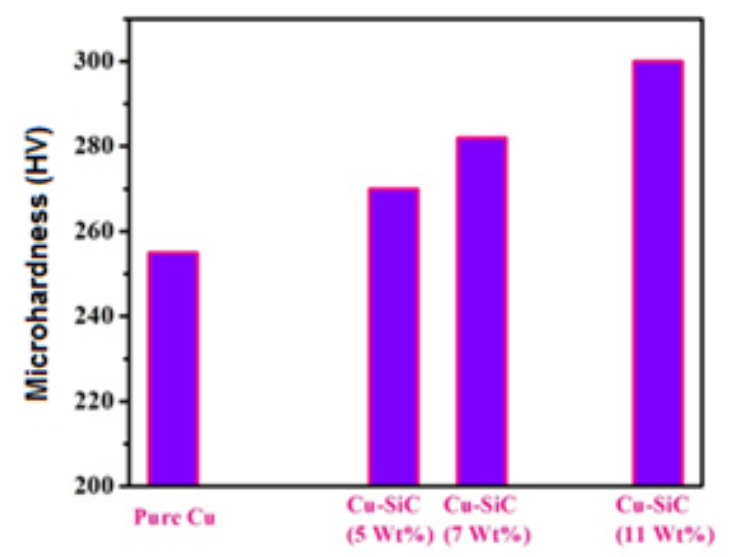

\section{Electrodeposited Cu-SiC nanocomposites}

Fig. 6.VickerMicrhardness (HV) of pure $\mathrm{Cu}$ and $\mathrm{Cu}-\mathrm{SiCnanocomposite} \mathrm{coatings}$

\section{F. Corrosion Resistance Studies}

Corrosion resistance measurements were performed for the electrodeposited pure $\mathrm{Cu}$ and $\mathrm{Cu}-\mathrm{SiCnanocomposites} \mathrm{by}$ electrochemical impedance spectroscopy (EIS) and Tafel polarization techniques and the results were presented in Table(2\&3).

\section{Electrochemical Impedance Spectroscopy (EIS) Analysis}

The electrochemical impedance spectroscopy (EIS) analysis was performed to evaluate the impact of $\mathrm{SiC}$ nanoparticles (NPs) on the corrosion resistance of the $\mathrm{Cu}-\mathrm{SiCnanocomposite}$ coatings is shown in Fig.7.The electrodeposited coatings of $1 \mathrm{~cm}^{2}$ area were immersed in $3.5 \mathrm{wt} \% \mathrm{NaCl}$ solutionact as working electrode and the commercial saturated calomel electrode (SCE) was used as the reference electrode for the measurement of all potentials. The platinum wire was used as auxiliary electrode in the three electrode cell assembly for the measurement of corrosion rate of the $\mathrm{Cu}$ and $\mathrm{Cu}$-SiCnanocomposite coatings. The electrochemical impedance nyquist plots were recorded and the charge transfer resistance $\left(\mathrm{R}_{\mathrm{ct}}\right)$ was measured for all the coatings and the results are tabulated (Table2). From the results, it is observed that the charge transfer resistance $\left(\mathrm{R}_{\mathrm{ct}}\right)$ was increased with increasing $\mathrm{SiC}$ content in the $\mathrm{Cu}$-SiCnanocomposite coating compared to electrodeposited pure copper coatings. It shows that the $\mathrm{Cu}-\mathrm{SiCnanocomposite}$ coatings were more corrosion resistance than the electrodeposited pure copper in $3.5 \mathrm{wt} \%$ $\mathrm{NaCl}$ solution.

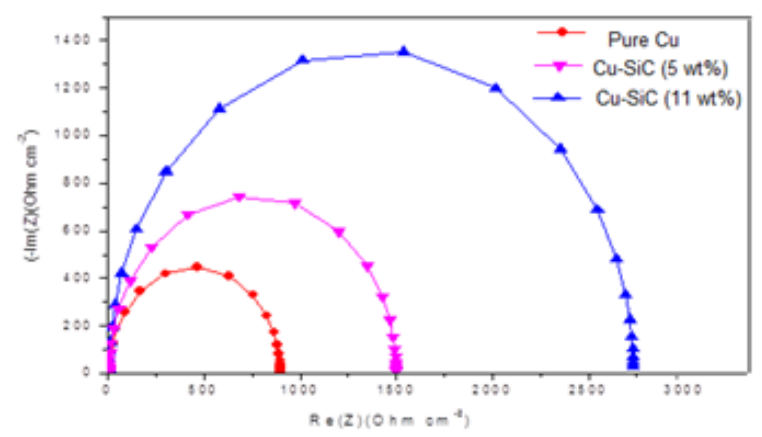

Fig.7.Nyquist plot of electrodeposited $\mathrm{Cu}$ and $\mathrm{Cu}-\mathrm{SiCnanocomposite} \mathrm{coatings.}$

Table2: Impedance parameter values for the $\mathrm{Cu}$ and $\mathrm{Cu}-\mathrm{SiCnanocomposite}$ electrodeposits.

\begin{tabular}{|l|c|c|}
\hline \multicolumn{1}{|c|}{$\begin{array}{c}\text { Electrodeposit } \\
\text { Details }\end{array}$} & $\begin{array}{c}\text { Weight \% of } \\
\mathbf{S i C}\end{array}$ & $\mathbf{R}_{\mathbf{c t}}\left(\mathbf{\Omega} / \mathbf{c m}^{2}\right)$ \\
\hline $\begin{array}{l}\text { Electrodeposited } \\
\text { copper }\end{array}$ & 0 & 898 \\
\hline Cu-SiCnanocomposite & 5 & 1501 \\
\hline Cu-SiCnanocomposite & 11 & 2733 \\
\hline
\end{tabular}

\section{Tafel Polarization Studies}

Tafel polarization studies were performed by immersing the working electrode (electrodeposit) of $1 \mathrm{~cm}^{2}$ area in $3.5 \mathrm{wt} \% \mathrm{NaCl}$ solution in a three electrode cell assembly and the results were presented in Table3(Fig. 8). The corrosion potential $\left(\mathrm{E}_{\text {corr }}\right)$, corrosion current $\left(\mathrm{i}_{\text {corr }}\right)$, and the tafel slopes ba and bc are calculated from the tafel polarization curves (Fig. 8) and are given in the Table3.

Table3:Tafel parameter values for the electrodeposited pure $\mathrm{Cu}$ and $\mathrm{Cu}-\mathrm{SiCnanocomposite} \mathrm{coatings.}$

\begin{tabular}{|l|c|c|c|c|}
\hline $\begin{array}{c}\text { Electrodeposit } \\
\text { Details }\end{array}$ & $\begin{array}{c}\text { Weig } \\
\text { ht \% } \\
\text { of } \\
\mathbf{S i C}\end{array}$ & $\begin{array}{c}\mathbf{E}_{\text {corr }} \\
(\mathbf{V}) \mathbf{v s} \\
\mathbf{S C E}\end{array}$ & $\begin{array}{c}\mathbf{I}_{\text {corr }} \\
(\boldsymbol{\mu A} \\
/ \mathbf{c m}^{2} \\
)\end{array}$ & $\begin{array}{c}\text { Corrosi } \\
\text { on rate } \\
(\mathbf{m m} / \mathbf{y e} \\
\mathbf{a r})\end{array}$ \\
\hline $\begin{array}{l}\text { Electrodeposited } \\
\text { copper }\end{array}$ & 0 & $\begin{array}{c}-227.7 \\
69\end{array}$ & $\begin{array}{c}13.8 \\
02\end{array}$ & 0.1599 \\
\hline $\begin{array}{l}\text { Cu-SiCnanocomp } \\
\text { osite }\end{array}$ & 5 & $\begin{array}{c}-241.8 \\
91\end{array}$ & $\begin{array}{c}12.5 \\
23\end{array}$ & 0.1451 \\
\hline $\begin{array}{l}\text { Cu-SiCnanocomp } \\
\text { osite }\end{array}$ & 11 & $\begin{array}{c}-348.1 \\
65\end{array}$ & $\begin{array}{c}4.89 \\
7\end{array}$ & 0.0567 \\
\hline
\end{tabular}


From the results, it is observed that the corrosion current $\left(\mathrm{i}_{\text {corr }}\right)$ and the corrosion rate $(\mathrm{CR})$ were decreased for all the $\mathrm{Cu}-\mathrm{SiCnanocomposites}$ compared to pure $\mathrm{Cu}$ coatings (Table3).

It shows that, $\mathrm{Cu}$-SiCnanocomposites were more corrosion resistance than the pure copper coatings (Table3).

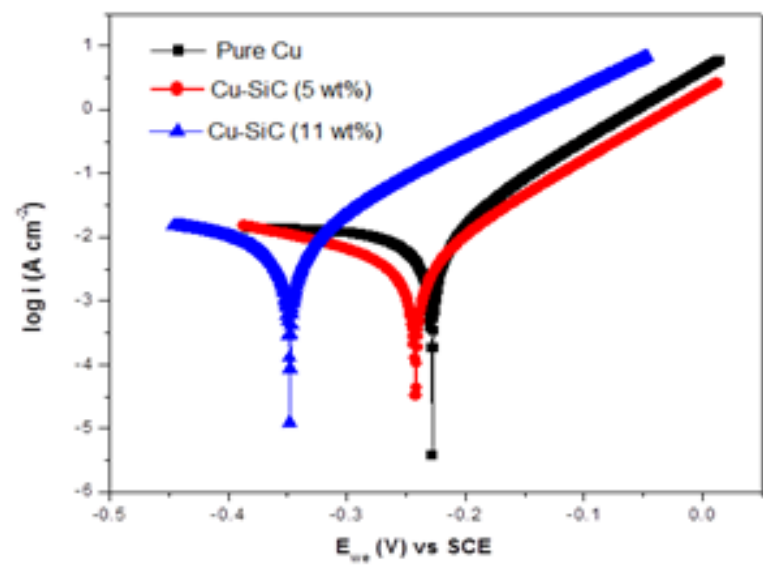

Fig. 8.Tafel plots of electrodeposited $\mathrm{Cu}$ and $\mathrm{Cu}$-SiCnanocomposite coatings.

\section{CONCLUSIONS}

The Nanostructured $\mathrm{Cu}$ and $\mathrm{Cu}-\mathrm{SiC}$ composite coatings were successfully fabricated by a simple electrodeposition technique and they were characterized by EDX, FESEM, XRD and Vickers Microhardness and Electrochemical AC impedance and Tafel polarization techniques for possible electrical contact material applications. Based on the results, the following conclusions were deduced.

- From the XRD studies, the grain size was measured by using Debye-Sherrer formula for $\mathrm{Cu}$ and $\mathrm{Cu}$-SiCnanocomposite coatings and found to be $\sim 35 \mathrm{~nm}$ and $\sim 33 \mathrm{~nm}$ respectively.

- The crystallite structure of $\mathrm{Cu}$ and $\mathrm{Cu}-\mathrm{SiCnanocomposite} \mathrm{coating} \mathrm{was} \mathrm{fcc} \mathrm{(face} \mathrm{centered}$ cubic) and the preferred orientation was (220).

- The Vickers microhardness of $\mathrm{Cu}-\mathrm{SiCnanocomposites}$ increased with increasing the $\mathrm{SiC}$ content in the composite coatings compared to pure copper coatings.

- The electrochemical impedance spectroscopy (EIS) and Tafel polarization studies confirmed that $\mathrm{Cu}$-SiCnanocomposite coatings was high corrosion resistance than electrodeposited pure copper in 3.5wt\% $\mathrm{NaCl}$ solution.

\section{REFERENCES}

1. Efe, G. C., Ipek, M., Zeytin, S., \&Bindal, C. (2012). An investigation of the effect of $\mathrm{SiC}$ particle size on $\mathrm{Cu}-\mathrm{SiC}$ composites. Composites Part B: Engineering, 43(4), 1813-1822.

2. Mirsaeed-Ghazi, S. M., Allahkaram, S. R., \&Molaei, A. (2018). Tribological Behavior and Corrosion Properties of Graphite Incorporated $\mathrm{Cu} / \mathrm{Sic}$ Nanocomposite Coatings Prepared by Pulse Current Electrodeposition. Inorganic Chemistry: An Indian Journal, $13,123$.

3. Ramalingam, S., Muralidharan, V. S., \&Subramania, A. (2009). Electrodeposition and characterization of $\mathrm{Cu}-\mathrm{TiO} 2$ nanocomposite coatings. Journal of Solid State Electrochemistry, 13(11), 1777-1783.

4. Allahkaram, S. R., Golroh, S., \&Mohammadalipour, M. (2011). Properties of $\mathrm{Al} 2 \mathrm{O} 3$ nano-particle reinforced copper matrix composite coatings prepared by pulse and direct current electroplating. Materials \& Design, 32(8-9), 4478-4484.

5. Ramalingam, S., Muralidharan, V. S., \&Subramania, A. (2013). Electrodeposition and characterisation of $\mathrm{Cu}-\mathrm{CeO} 2$ nanocomposite coatings. Surface Engineering, 29(7), 511-515

6. Zamblau, I., Varvara, S., \&Muresan, L. M. (2011). Corrosion behavior of $\mathrm{Cu}-\mathrm{SiO} 2$ nanocomposite coatings obtained by electrodeposition in the presence of cetyltrimethyl ammonium bromide. Journal of materials science, 46(20), 6484-6490.

7. Robin, A., de Santana, J.C.P., \&Sartori, A. F. (2010). Characterization of copper-silicon nitride composite electrocoatings. Journal of applied electrochemistry, 40(3), 507-513.

8. Ramalingam, S., Balakrishnan, K., \&Subramania, A. (2015) Mechanical and corrosion resistance properties of electrodeposited $\mathrm{Cu}-\mathrm{ZrO} 2$ nanocomposites. Transactions of the IMF, 93(5), 262-266.

9. Eslami, M., Saghafian, H., Golestani-fard, F., \& Robin, A. (2014). Effect of electrodeposition conditions on the properties of $\mathrm{Cu}-\mathrm{Si} 3 \mathrm{~N} 4$ composite coatings. Applied surface science, 300, 129-140.

10. Maharana, H. S., \&Basu, A. (2018). Effects of Different Surfactants on Structural, Tribological and Electrical Properties of Pulsed Electro-Codeposited $\mathrm{Cu}-\mathrm{ZrO} 2$ Composite Coatings. Journal of Materials Engineering and Performance, 27(4), 1854-1865.

11. Ramalingam, S., Balakrishnan, K., Shanmugasamy, S. \&Subramania, A.(2017). Electrodeposition and characterisation of $\mathrm{Cu}-\mathrm{MWCNTs}$ nanocomposite coatings. Surface Engineering, 33(5), 369-374.

12. Mangam, V., Das, K., \& Das, S. (2010). Structure and properties of electrocodeposited $\mathrm{Cu}-\mathrm{CeO} 2$ nanocomposite thin films. Materials Chemistry and Physics, 120(2-3), 631-635.

13. Dehgahi, S., Amini, R., \&Alizadeh, M. (2017). Microstructure and corrosion resistance of $\mathrm{Ni}-\mathrm{Al} 2 \mathrm{O} 3-\mathrm{SiC}$ nanocomposite coatings produced by electrodeposition technique. Journal of Alloys and Compounds, 692, 622-628.

14. Nechiche, M., Gauthier-Brunet, V., Eyidi, D., Azem, S., \& Dubois, S. (2015). Ni-Coated SiC Particles: Synthesis and Densification. Journal of the American Ceramic Society, 98(12), 4058-4065.

15. Liu, W. Q., Lei, W. N., Wang, C. Y., Qian, H. F., \& Ding, L. H. (2015). Ni-SiCnanocomposites electroplating process under ultrasonic and agitation. Integrated Ferroelectrics, 167(1), 192-198.

16. Lekka, M., Koumoulis, D., Kouloumbi, N., \&Bonora, P. L. (2009) Mechanical and anticorrosive properties of copper matrix micro-and nano-composite coatings. ElectrochimicaActa, 54(9), 2540-2546.

17. Robin, A., de Santana, J. C. P., \&Sartori, A. F. (2011). Co-electrodeposition and characterization of $\mathrm{Cu}-\mathrm{Si} 3 \mathrm{~N} 4$ composite coatings. Surface and Coatings Technology, 205(19), 4596-4601.

18. Miguel, F. L., Müller, R., Mathur, S., \&Mücklich, F. (2015). Microstructure and mechanical properties of electrodeposited $\mathrm{Ni}$ and $\mathrm{Ni}$-matrix-nanocomposite thin films. Materials Science and Engineering: A, 646, 254-262.

19. Zeng, Y. B., Qu, N. S., \& Hu, X. Y. (2014). Preparation and characterization of electrodeposited $\mathrm{Ni}-\mathrm{CeO} 2$ nanocomposite coatings with high current density. International Journal of Electrochemical Science, 9, 8145-54.

20. Qu, N. S., Hu, X. Y., Qian, W. H., \& Zhu, Z. W. (2014). Enhancement of microhardness and wear resistance of $\mathrm{Ni}-\mathrm{CeO} 2$ nanocomposite coatings. Surface Engineering, 30(3), 159-164.

21. Phala, M. F., \&Fayomi, O. S. I. (2017). Corrosion and Properties of Developed Ni-CeO2 Co-deposited on Mild Steel at Varying Current Densities. Procedia Manufacturing, 7, 543-548.

22. Ning, D., Zhang, A., Murtaza, M., \& Wu, H. (2019). Effect of surfactants on the electrodeposition of $\mathrm{Cu}-\mathrm{TiO} 2$ composite coatings prepared by jet electrodeposition. Journal of Alloys and Compounds, 777, 1245-1250.

23. Mandal, P., \&Mondal, S. C. (2018). Investigation of electro-thermal property of Cu-MWCNT-coated 316L stainless steel. Surface Engineering, 34(9), 697-704.

24. Lee, H. K., Lee, H. Y., \&Jeon, J. M. (2007). Codeposition of micro-and nano-sized $\mathrm{SiC}$ particles in the nickel matrix composite coatings obtained by electroplating. Surface and Coatings Technology, 201(8), 4711-4717.

25. Walsh, F. C., \& Ponce de Leon, C. (2014). A review of the electrodeposition of metal matrix composite coatings by inclusion of particles in a metal layer: an established and diversifying technology Transactions of the IMF, 92(2), 83-98.

26. Aruna, S. T., Lashmi, P. G., \&Seema, H. M. (2016). The effect of additives on the properties of electrodeposited $\mathrm{Ni}$-zircon composite coatings. RSC Advances, 6(14) $11185-11192$ 
27. Arghavanian, R., \&Parvini-Ahmadi, N. (2011). The effect of co-electrodeposited $\mathrm{ZrO} 2$ particles on the microstructure and corrosion resistance of $\mathrm{Ni}$ coatings. Journal of Solid State Electrochemistry, 15(10), 2199-2204.

28. Arai, S., Saito, T., \& Endo, M. (2010). Cu-MWCNT composite films fabricated by electrodeposition. Journal of The Electrochemical Society, 157(3), D147-D153.

29. Maharana, H. S., Lakra, S., Pal, S., \&Basu, A. (2016). Electrophoretic Deposition of Cu-SiO 2 Coatings by DC and Pulsed DC for Enhanced Surface-Mechanical Properties. Journal of Materials Engineering and Performance, 25(1), 327-337.

30. Chen, J., Li, J., Xiong, D., He, Y., Ji, Y., \& Qin, Y. (2016). Preparation and tribological behavior of Ni-graphene composite coating under room temperature. Applied Surface Science, 361, 49-56.

31. Ning, D., Zhang, A., \& Wu, H. (2019). Cu-TiO2 composites with high incorporated and uniform distributed $\mathrm{TiO} 2$ particles prepared by jet electrodeposition. Surface Engineering, 35 (12), 1048-1054.

32. Mandal, P., \&Mondal, S. C. (2018). Investigation of Electro-Thermal property for $\mathrm{Cu}-\mathrm{MWCNT}$ composite coating on anodized 6061 aluminium alloy. Applied Surface Science, 454, 138-147.

33. Zhu, J., Liu, L., Zhao, H., Shen, B., \& Hu, W. (2007). Microstructure and performance of electroformed $\mathrm{Cu} /$ nano-SiC composite. Materials \&Design, 28(6), 1958-1962.

34. Zhu, J., Liu, L., Hu, G., Shen, B., Hu, W., \& Ding, W. (2004). Study on composite electroforming of $\mathrm{Cu} / \mathrm{SiCp}$ composites. Materials Letters, 58(10), 1634-1637.

35. Banthia, S., Sengupta, S., Das, S., \& Das, K. (2019). Synthesis and characterization of novel $\mathrm{Cu}, \mathrm{Cu}-\mathrm{SiC}$ functionally graded coating by pulse reverse electrodeposition. Applied Surface Science, 467, 567-579.

36. Mirsaeed-Ghazi, S. M., Allahkaram, S. R., \&Molaei, A. (2019). Development and investigation of $\mathrm{Cu} / \mathrm{SiCnano-composite} \mathrm{coatings}$ via various parameters of DC electrodeposition. Tribology International, 134, 221-231.

37. Mirsaeedghazi, S. M., Allahkaram, S. R., Mahdavi, S., \&Varmazyar, A. (2018). Characteristics and properties of $\mathrm{Cu} /$ nano-SiC and $\mathrm{Cu} /$ nano-SiC/graphite hybrid composite coatings produced by pulse electrodeposition technique. Canadian Metallurgical Quarterly, 57(3), 358-366.

38. Pradhan, A. K., \& Das, S. (2014). Pulse-reverse electrodeposition of $\mathrm{Cu}-\mathrm{SiCnanocomposite} \mathrm{coating:} \mathrm{effect} \mathrm{of} \mathrm{concentration} \mathrm{of} \mathrm{SiC}$ in the electrolyte. Journal of Alloys and Compounds, 590, 294-302.

39. Guglielmi, N. (1972). Kinetics of the deposition of inert particles from electrolytic baths. Journal of the Electrochemical Society, 119(8), 1009-1012.

\section{AUTHORS PROFILE}

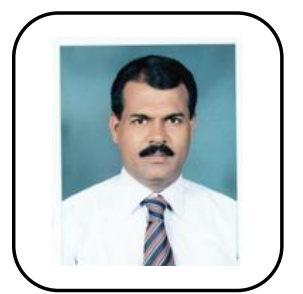

Dr. S. Ramalingam obtained his M.Sc., M.Phil. \&Ph.D. degree from Department of Industrial Chemistry, Alagappa University, Karaikudi-630 003, Tamil Nadu, India. Presently, he is working as Assistant Professor in the Department of Chemistry, School of Advanced Sciences (SAS), Kalasalingam Academy of Research and Education (Deemed to be University), Krishnankoil-626 126, Tamil Nadu, India. He has 12 years of Teaching and Research Experience and 8 years of Industrial experience. His research areas of interest areElectrodeposition \& Corrosion and Nanomaterials Chemistry and published severalarticles in reputedinternational / national journals. He is a Fellow Life member in the Society for Advancement of Electrochemical Science \& Technology (SAEST), CECRI, Karaikudi-630 003, Tamil Nadu, India and Life member in Association of Chemistry Teachers (ACT), TIFR, Mumbai-400 007, India. 